\title{
Involvement of oxidative stress in the enhancement of acetylcholinesterase activity induced by amyloid beta-peptide
}

\author{
Joana Barbosa Melo, Paula Agostinho, Catarina Resende Oliveira* \\ Center for Neurosciences of Coimbra and Faculty of Medicine, University of Coimbra, 3004-504 Coimbra, Portugal
}

Received 9 May 2002; accepted 2 October 2002

\begin{abstract}
Acetylcholinesterase (AChE) activity is increased within and around amyloid plaques, which are present in Alzheimer's disease (AD) patient's brain. In this study, using cultured retinal cells as a neuronal model, we analyzed the effect of the synthetic peptide $\mathrm{A} \beta_{25-35}$ on the activity of $\mathrm{AChE}$, the degradation enzyme of acetylcholine, as well as the involvement of oxidative stress in this process. The activity of AChE was increased when retinal cells were incubated with $\mathrm{A} \beta_{25-35}(25 \mu \mathrm{M}, 24 \mathrm{~h})$ and antioxidants such as $\alpha$-tocopherol acetate and nitric oxide synthase (NOS) inhibitors were capable of preventing this effect. Despite $A \beta_{25-35}$ did not affect cell membrane integrity, the redox capacity of cells decreased. The incubation with this amyloidogenic peptide led to an increment of reactive oxygen species formation (20\%), of lipid peroxidation (65\%), and basal intracellular calcium levels (40\%). The data obtained show that the enhancement of $\mathrm{AChE}$ activity induced by $\mathrm{A} \beta_{25-35}$ is mediated by oxidative stress, and that vitamin $\mathrm{E}$ and NOS inhibitors, by preventing the compromise of the enzyme activity, can have an important role in the maintenance of acetylcholine synaptic levels, thus preventing or improving cognitive and memory functions of AD patients.

(C) 2002 Elsevier Science Ireland Ltd and the Japan Neuroscience Society. All rights reserved.
\end{abstract}

Keywords: Acetylcholinesterase; Beta-amyloid; Oxidative stress; Nitric oxide synthase; Retinal cells

\section{Introduction}

The major constituent of senile plaques, occurring in Alzheimer's disease (AD), is amyloid $\beta$-peptide $(\mathrm{A} \beta)$, a 40-42 amino acid peptide, which is a cleaved form of the amyloid precursor protein (APP) (Kang et al., 1987; Tanzi et al., 1988). A $\beta$ seems to play a crucial role in the pathogenesis of $\mathrm{AD}$, however the mechanism and the cellular pathways involved in the neuronal degeneration induced by this peptide are not fully understood. It was demonstrated that above a threshold concentration $A \beta$ peptides act as potent neurotoxins both in vitro and in vivo (Pereira et al., 1999; Harkany et al., 1999; Kasa et al., 2000; Zhu et al., 2000). Accumulating evidence suggests that oxidative stress is involved in the mechanism of A $\beta$-induced neurotoxicity (Behl et al., 1992; Butterfield et al., 1994; Mattson et al., 1995; Bus et al., 1999; Huang et al., 1999; Pereira et al., 1999).

\footnotetext{
* Corresponding author. Tel.: +351-239820190; fax: +351239822776

E-mail address: catarina@cnc.cj.uc.pt (C.R. Oliveira).
}

Besides $\mathrm{A} \beta$ deposition, selective neuronal loss is another hallmark of AD brains, especially with dysfunction and degeneration of basal forebrain cholinergic neurons, which project to hippocampus and neocortex (Geula and Mesulam, 1994). However, the cause of the basal forebrain cholinergic neurons vulnerability and its relationship to $A \beta$ peptides remains unclear. One of the characteristic changes that occurs in $\mathrm{AD}$ is the loss of acetylcholinesterase (AChE) activity, the enzyme responsible for acetylcholine hydrolysis, from both cholinergic and non-cholinergic neurons of the brain (Atack et al., 1983). However, AChE activity has been shown to be increased within and around amyloid plaques (Ulrich et al., 1990; Morán et al., 1993), to promote the assembly of amyloid beta-peptides into fibrils (Inestrosa et al., 1996) and to increase the cytotoxicity of these peptides (Alvarez et al., 1998). These reports suggest that AChE could play a pathogenic role in AD by influencing the process leading to amyloid toxicity.

In this study we assessed AChE activity and the kinetic parameters of the enzyme activity when cells are incubated with $A \beta_{25-35}$. Considering that $A \beta_{25-35}$ is 
known to induce cytotoxicity through mechanisms involving oxidative stress, we studied the effect of some antioxidants in preventing the increase of $\mathrm{AChE}$ activity induced by $\mathrm{A} \beta_{25-35}$, using chick retinal cells as a neuronal model.

\section{Materials and methods}

\subsection{Material}

Basal Medium Eagle (BME) was purchased from Sigma, USA; trypsin from Gibco and fetal calf serum from Biochrom, KG. The synthetic peptides $A \beta_{25-35}$ and $A \beta_{35-25}$ were obtained from Bachem, Germany. 1(4-(Trimethylammonium)-phenyl)-6-phenylhexa-1,3,5triene (TMA-DPH) and 2',7'-dichlorofluorescin diacetate $\left(\mathrm{DCFH}_{2}\right.$-DA) were obtained from Molecular Probes, Eugene, OR. D- $\alpha$-Tocopherol acetate (vitamin E) was purchased from Fluka, Buchs, Switzerland. LNAME and 7-nitroindazole were obtained from Sigma, USA. All other chemicals used were purchased from Sigma, USA or Merck, Germany, and were of analytical grade.

\subsection{Culture of chick retinal cells}

Retinal cells were prepared from 8-day-old chick (White Leghorn) embryos and cultured in BME, buffered with $20 \mathrm{mM}$ Hepes and $10 \mathrm{mM} \mathrm{NaHCO}$, and supplemented with $5 \%$ fetal calf serum, penicillin (100 $\mathrm{U} / \mathrm{ml})$ and streptomycin $(100 \mu \mathrm{g} / \mathrm{ml})$ as previously described (Agostinho et al., 1994). The cells were plated at density of a $0.4 \times 10^{6}$ cells $/ \mathrm{cm}^{2}$ on poly-L-lysine $(0.1$ $\mathrm{mg} / \mathrm{ml}$ ) coated glass coverslips, for fluorescence measurements and on 12-multiwell plates, also coated with poly-L-lysine, for the other experiments. The cells were kept in culture for $5-6$ days at $37{ }^{\circ} \mathrm{C}$ in a humidified atmosphere of $5 \% \mathrm{CO}_{2}$ and $95 \%$ air, before the experiments. Similar cultures were previously described to be enriched in amacrine-like neurons, but also containing neurons resembling bipolar cells and a few glial cells (Agostinho et al., 1996; Carvalho et al., 1998).

\subsection{Cell treatments and viability analysis}

The peptides $A \beta_{25-35}$ or $A \beta_{35-25}$, previously solubilized in sterile miliQ water, were added to the culture medium $24 \mathrm{~h}$ before the experiments in a final concentration of $25 \mu \mathrm{M}$. Vitamin E (D- $\alpha$-tocopherol acetate), solubilized in dimethyl sulfoxide (DMSO), was added to the cells $20 \mathrm{~h}$ before the exposure to the peptide in a final concentration of $20 \mu \mathrm{M}$. The final concentration of DMSO was $0.2 \%$, and did not affect cell viability (data not show). L-NAME $(250 \mu \mathrm{M})$ and 7-nitroindazole (50 $\mu \mathrm{M}$ ), solubilized in water, were incubated 30 min before exposure of cells to the peptide.

The viability of retinal cells was determined by monitoring the leakage of lactate dehydrogenase $(\mathrm{LDH})$ and the capacity of the cells to reduce the 3(4,5-dimethylthiazol-2-yl)-2,5-diphenyltetrazolium bromide (MTT) salt to formazan. LDH activity was measured spectrophotometrically, according to the method described by Bergmeyer and Brent (1974), following the rate of conversion of NADH to NAD ${ }^{+}$ at $340 \mathrm{~nm}$. To calculate the intracellular LDH activity the cells were lysed with $10 \mathrm{mM}$ Hepes (pH 7.4). LDH released into the extracellular medium was expressed as a percentage of the total LDH activity in the cells. The ability of cells to reduce MTT was measured spectrophotometrically at $570 \mathrm{~nm}$, according to Mosmann (1983). In brief, MTT, dissolved in sodium medium (pH 7.4) at $5 \mathrm{mg} / \mathrm{ml}$, was incubated with the cells for $3 \mathrm{~h}$ at $37{ }^{\circ} \mathrm{C}$. After this period an equal volume of acid isopropanol $(0.04 \mathrm{M} \mathrm{HCl}$ in isopropanol) was added to each well and mixed until all the formazan crystals were dissolved. MTT reduction was expressed as a percentage of control cells absorbance.

\subsection{AChE activity}

Cells were lysed in $15 \mathrm{mM}$ Tris ( $\mathrm{pH} 7.4)$, on ice, and AChE activity was measured using a spectrophotometric method (Ellman et al., 1961; Harkany et al., 1999). Acetylthiocholine iodide (ACThCh) was used as a substrate, in a concentration of $0.5 \mathrm{mM}$. Ethopropasine- $\mathrm{HCl}\left(10^{-4} \mathrm{M}\right)$ was used to inhibit non-specific esterases. The activity of AChE was expressed as nanomole of ACThCh hydrolyzed $/ \mathrm{min} / \mathrm{mg}$ protein, as measured spectrophotometrically at $414 \mathrm{~nm}$. The kinetics of AChE was determined by using increasing concentrations of acetylthiocholine, in the range of $0.03-1.0 \mathrm{mM}$. The $\mathrm{K}_{\mathrm{m}}$ and $V_{\max }$ values of the enzyme were calculated by regression analysis of the linear portions of the Lineweaver-Burk plots $(1 / V$ vs $1 / S)$ (Alvarez et al., 1998).

\subsection{Measurement of intracellular reactive oxygen species formation}

Formation of intracellular peroxides was detected by fluorescence spectroscopy using a non-fluorescent compound, $\mathrm{DCFH}_{2}-\mathrm{DA}$, which is desterified within cells by endogenous esterases to the acid $2^{\prime}, 7^{\prime}$-dichlorofluorescin $\left(\mathrm{DCFH}_{2}\right)$, as previously described (Pereira et al., 1999). This ionized free acid is trapped within the cells and is capable of being oxidized to fluorescent $2^{\prime}, 7^{\prime}$-dichlorofluorescein (DCF) by hydroperoxides, although other mechanism of oxidation cannot be ruled out (Cathcart et al., 1983). Retinal cells, cultured in glass coverslips, were loaded with $5 \mu \mathrm{M} \mathrm{DCFH}{ }_{2}$-DA for $30 \mathrm{~min}$, at 
$37{ }^{\circ} \mathrm{C}$, in a saline medium $\left(\mathrm{Na}^{+}\right.$-medium) containing (in $\mathrm{mM}$ ): $132.0 \mathrm{NaCl}, 4.0 \mathrm{KCl}, 1.0 \mathrm{CaCl}_{2}, 1.4 \mathrm{MgCl}_{2}, 1.2$ $\mathrm{NaH}_{2} \mathrm{PO}_{4}, 6.0$ glucose, 10.0 Hepes ( $\mathrm{pH}$ 7.4). Then, the cells were washed and were incubated in $\mathrm{Na}^{+}$-medium, for $15 \mathrm{~min}$ at $37{ }^{\circ} \mathrm{C}$, to allow desterification of $\mathrm{DCFH}_{2}-$ DA. After this period, the glass coverslips were mounted in a special holder (Perkin-Elmer L225008) and fluorescence was measured using a computer-assisted spectrofluorophotometer, at $502 \mathrm{~nm}$ excitation and $550 \mathrm{~nm}$ emission, for $30 \mathrm{~min}$.

\subsection{Measurement of the extent of lipid peroxidation}

The extent of lipid peroxidation was determined by the thiobarbituric acid method (Buege and Aust, 1967). After exposure of cells to $A \beta_{25-35}$ peptide, the culture medium was removed and replaced by an ice-cold solution of $15 \mathrm{mM}$ Tris ( $\mathrm{pH} 7.4)$, with the multi-wells on ice. The cells were scrapped off and diluted three times with $15 \%$ trichloroacetic acid (TCA), $0.375 \%$ thiobarbituric acid, $0.25 \mathrm{M} \mathrm{HCl}$, and $0.015 \%$ 2,6-ditert-butyl-4-methylphenol (BHT), and incubated for 15 min at $100{ }^{\circ} \mathrm{C}$. Then, the samples were centrifuged at $95.5 \times g_{\text {av }}$ for $10 \mathrm{~min}$, the supernatants were collected and the absorbance was measured at $530 \mathrm{~nm}$. The amount of thiobarbituric acid-reactive substances (TBARS) formed was calculated using a molar extinction coefficient of $1.56 \times 10^{5} / \mathrm{mol} / \mathrm{cm}$ and expressed as nanomoles of TBARS produced per milligram of protein. Protein content was determined by the Sedmak method (Sedmak and Grossero, 1977), using bovine serum albumin as the standard.

\section{7. $\left[\mathrm{Ca}^{2+}\right]_{i}$ measurements}

Retina cells cultured on glass coverslips were incubated with $3 \mu \mathrm{M}$ Indo-AM, in BME buffered with 20 $\mathrm{mM}$ Hepes, for $45 \mathrm{~min}$ at $37{ }^{\circ} \mathrm{C}$. The cells were further incubated in Krebs buffer containing (in $\mathrm{mM}$ ): 132 $\mathrm{NaCl}, 4 \mathrm{KCl}, 1 \mathrm{CaCl}_{2}, 1.4 \mathrm{MgCl}_{2}, 6$ glucose and 10 Hepes, (pH 7.4) for $15 \mathrm{~min}$, to allow the complete hydrolysis of the acetoxymethylester precursor of Indo1. Then, the cells were rinsed with Krebs buffer and placed in a special holder (Perkin-Elmer L225008), inside a cuvette with an alignment of $60^{\circ}$ to the excitation beam in order to minimize the effect of light reflection. The fluorescence was measured with excitation of $335 \mathrm{~nm}$ and emission at $410 \mathrm{~nm}$, using $5 \mathrm{~nm}$ slits. The free intracellular $\mathrm{Ca}^{2+}$ concentration $\left[\mathrm{Ca}^{2+}\right]_{\mathrm{i}}$ was calculated as previously described (Agostinho et al., 1997), $F_{\max }$ being calculated upon addition of $3 \mu \mathrm{M}$ ionomycin, and the autofluorescence determined with 3 $\mathrm{mM} \mathrm{MnCl}$.

\subsection{Membrane anisotropy measurements}

For these experiments, retinal cells were cultured in glass coverslips and the membrane order was measured by fluorescence analysis, by using the probe TMA-DPH, as previously described (Rego et al., 1998). After incubation with the peptides or/and vitamin $\mathrm{E}$, the coverslips were washed with a sodium saline solution (pH 7.4) and placed in a special holder (Perkin-Elmer L225008) inside a cuvette with an alignment of $60^{\circ}$ to the excitation beam, in order to minimize the effect of light reflection. Then, TMA-DPH at a final concentration of $1.5 \mu \mathrm{M}$, was added and after 20 min fluorescence anisotropy was determined using a computer-assisted spectrofluorophotometer (Perkin-Elmer LS 50 B) with a controlled polarizer system, with excitation wavelength at $360 \mathrm{~nm}$ and emission at $430 \mathrm{~nm}$. The probe showed to be rapidly incorporated in retinal cells, the labeling by TMA-DPH being maximal after about $15-20 \mathrm{~min}$, as determined by a time drive fluorescence measurement (not shown). The fluorescence anisotropy data were calculated according to Shinitzky and Barenholz (1978). An increase in fluorescence anisotropy $(r)$ values indicates a decrease in the probe mobility, reflecting an increase in membrane structural order or, in other terms, a decrease in membrane fluidity (Van Blitterswijk et al., 1981).

\subsection{Protein oxidation determination}

Protein carbonyl content was determined as described by Levine et al. (1990) with slight modifications (Cardoso et al., 1999). Cell suspensions were incubated with $10 \mathrm{mM}$ DNPH in $2 \mathrm{~N} \mathrm{HCl}$ (or with $2 \mathrm{~N} \mathrm{HCl}$ alone for the blanks), for $1 \mathrm{~h}$ at room temperature. The protein hidrazone derivatives were precipitated with $20 \%$ TCA, and the precipitates were washed three times with ethanol:ethylacetate (1:1). The final pellet was ressuspended and incubated in $6 \mathrm{M}$ guanidine $\mathrm{HCl}$, for $15 \mathrm{~min}$ at $37{ }^{\circ} \mathrm{C}$. The carbonyl content was determined spectrophotometrically at $360 \mathrm{~nm} \quad(\varepsilon=22000 / \mathrm{M} / \mathrm{cm})$ and expressed as $\mathrm{nmol} / \mathrm{mg}$ protein.

\subsection{Statistical analysis}

All data were expressed as mean \pm SEM. Statistical significance analysis was determined by using the unpaired two-tailed Student's $t$-test, after analysis of variance. A $P$ value less than 0.05 was considered significant.

\section{Results}

Retinal cells in culture were used as a neuronal model (Santos et al., 1998), in order to study the effect of the 
amyloidogenic peptide $A \beta_{25-35}$ on AChE activity and to evaluate whether oxidative stress is involved in this process. Retinal cells were incubated during $24 \mathrm{~h}$ with the synthetic peptide $A \beta_{25-35}$, the neurotoxic sequence of A $\beta$ protein (Pike et al., 1993; Pereira et al., 1999), in a final concentration of $25 \mu \mathrm{M}$. The reverse non-toxic sequence of $\mathrm{A} \beta_{25-35}$ peptide $\left(\mathrm{A} \beta_{35-25}\right)$ was used as a control. In our experimental conditions, the exposition of cells to $A \beta_{25-35}$ for $24 \mathrm{~h}$ did not affect cell membrane integrity, as assessed by the leakage of the cytoplasmatic enzyme LDH. Indeed, the amount of LDH released by control cells and by cells treated with the reverse sequence peptide, $\mathrm{A} \beta_{35-25},(14.2 \pm 1.0 \%$ of total and $13.6 \pm 1.3 \%$ of total, respectively) was not significantly $(P>0.05)$ different from that released by cells treated with $\mathrm{A} \beta_{25-35}$ peptide $(15.4 \pm 1.17 \%$ of total) (Table 1$)$. However, the cellular capacity to reduce the tetrazolium salt MTT was decreased upon incubation with $\mathrm{A} \beta_{25-35}$ $(65.8 \pm 1.6 \%)$, when compared to control cells $(100.1 \pm$ $2.0 \%$ ) or with cells treated with the reverse sequence peptide $A \beta_{35-25}(97.8 \pm 4.4 \%)$, as showed in Table 1. A dose-response curve of the effect of $A \beta_{25-35}$ peptide (5$100 \mu \mathrm{M}$ ) on MTT reduction (Fig. 1) was performed, and it was observed that $25 \mu \mathrm{M}$ of this peptide induces a significant $(P<0.01)$ decrease of cellular metabolic activity without affecting cell membrane integrity. The effect of $5 \mu \mathrm{M}$ of the full-length peptide $\mathrm{A} \beta_{1-40}$, incubated for $24 \mathrm{~h}$, on cellular capacity to reduce MTT was similar $(66.6 \pm 3.4 \%)$ to the effect observed for the synthetic peptide $A \beta_{25-35}(25 \mu \mathrm{M} ; 24 \mathrm{~h})$ (data not shown). Once, it has been reported that $A \beta_{25-35}$ accelerates the MTT formazan exocytosis (Liu and Schubert, 1997; Abe and Saito, 1999), cells treated or not (control cells) with $\mathrm{A} \beta_{25-35}$, for $24 \mathrm{~h}$, were incubated with MTT solution for different times $(0-180 \mathrm{~min})$. It was observed that in $A \beta_{25-35}$-treated cells the amount of MTT formazan formed was lower than that occurring in control cells for all the times studied (Fig. 1B). These results suggest an alteration in metabolic activity, rather than an effect on MTT formazan exocytosis induced by $\mathrm{A} \beta_{25-35}$ peptide. Furthermore, we have recently shown

Table 1

Effect of A $\beta$ peptides on LDH leakage and on MTT reduction, in retinal cells

\begin{tabular}{llll}
\hline & Control & $\mathrm{A} \beta_{35-25}$ & $\mathrm{~A} \beta_{25-35}$ \\
\hline \% LDH release & $14.2 \pm 1.0(13)$ & $13.6 \pm 1.3(4)$ & $15.4 \pm 1.17(9)$ \\
$\%$ MTT reduction & $100.1 \pm 2.0(14)$ & $97.8 \pm 4.4(6)$ & $65.8 \pm 1.6^{* *}(12)$
\end{tabular}

Cultured retinal cells were exposed to $25 \mu \mathrm{M}$ of $\mathrm{A} \beta_{35-25}$ or $\mathrm{A} \beta_{25-35}$ peptide, for $24 \mathrm{~h}$. LDH release and MTT reduction ability were determined spectrophotometrically, as described in Section 2. Values represent means \pm SEM of the number of experiments indicated, run in duplicate.

** $P<0.01$ values significantly different from cells not treated (control cells).

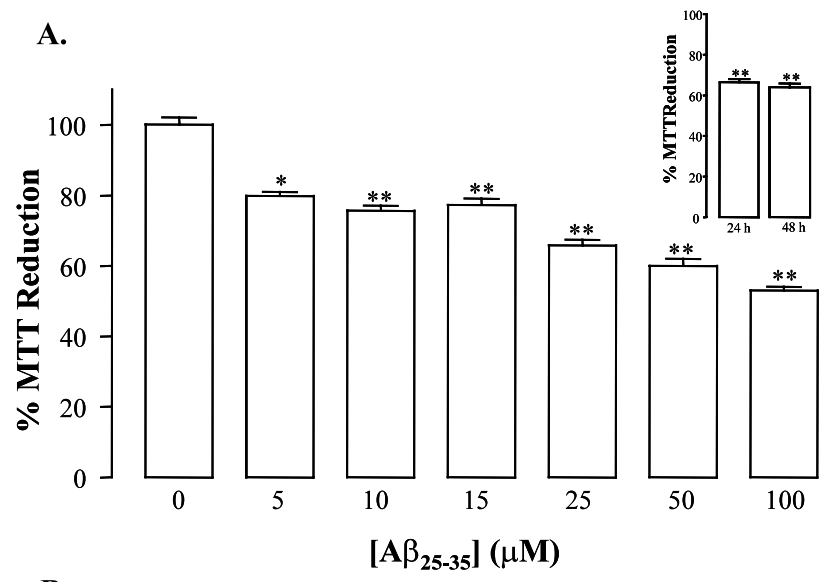

B.

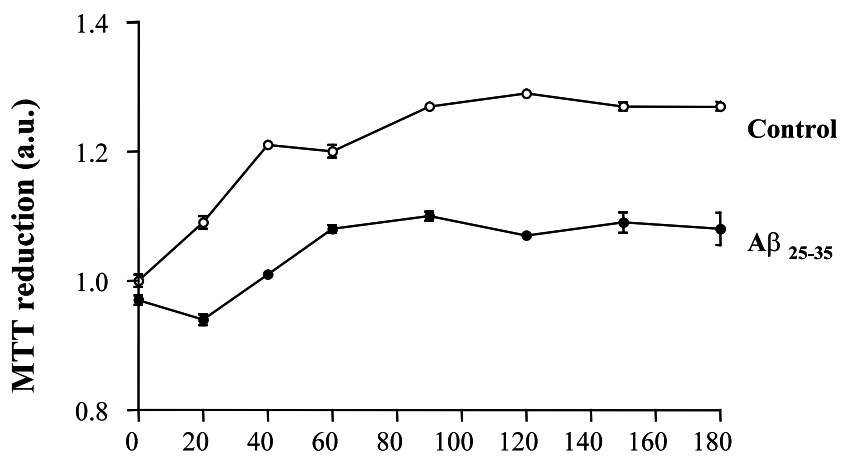

Time (min)

Fig. 1. Effect of $A \beta_{25-35}$ peptide on cellular metabolic capacity, assessed by MTT assay. (A) After treatment with the peptide at various concentrations $(0,5,10,15,25,50$ and $100 \mu \mathrm{M})$ for $24 \mathrm{~h}$, the reduction of the tetrazolium salt MTT to formazan was measured spectrophotometrically at $570 \mathrm{~nm}$, and expressed as a percentage relatively to control cells. Insert. Effect of $A \beta_{25-35}$ peptide $(25 \mu \mathrm{M})$ on cellular metabolic capacity after $24 \mathrm{~h}$ or $48 \mathrm{~h}$ of treatment; (B) Timecourse of the amount of MTT formazan formed in control $(\bigcirc)$ and $\mathrm{A} \beta_{25-35}$ peptide-treated cells $(\bullet)$. The values represent means \pm SEM of 3-14 experiences run in duplicate. ${ }^{*} P<0.05$ values significantly different from cells not treated with $\mathrm{A} \beta_{25-35} ;{ }^{* *} P<0.01$ values significantly different from cells not treated with $\mathrm{A} \beta_{25-35}$.

that $A \beta_{25-35}$ induces a decrease in glucose uptake and in pyruvate levels, thus reforcing the impairment of metabolic activity caused by this peptide. (Melo et al., in press).

\subsection{A $\beta_{25-35}$ increases $A C h E$ activity}

The activity of AChE, the enzyme responsible for acetylcholine degradation, was significantly increased $(P<0.001)$ in cells incubated with the $\mathrm{A} \beta_{25-35}$ peptide $(25 \mu \mathrm{M}$ for $24 \mathrm{~h}$ ) when comparing with cells treated with the reverse sequence peptide $\mathrm{A} \beta_{35-25}(25 \mu \mathrm{M}, 24 \mathrm{~h})$ or with untreated cells (Fig. 2). In cells treated with $\mathrm{A} \beta_{25-35}$ for $18 \mathrm{~h}$ the activity of AChE $(102 \pm 7.4 \%$ of control cells) was not significantly $(P>0.05)$ different 


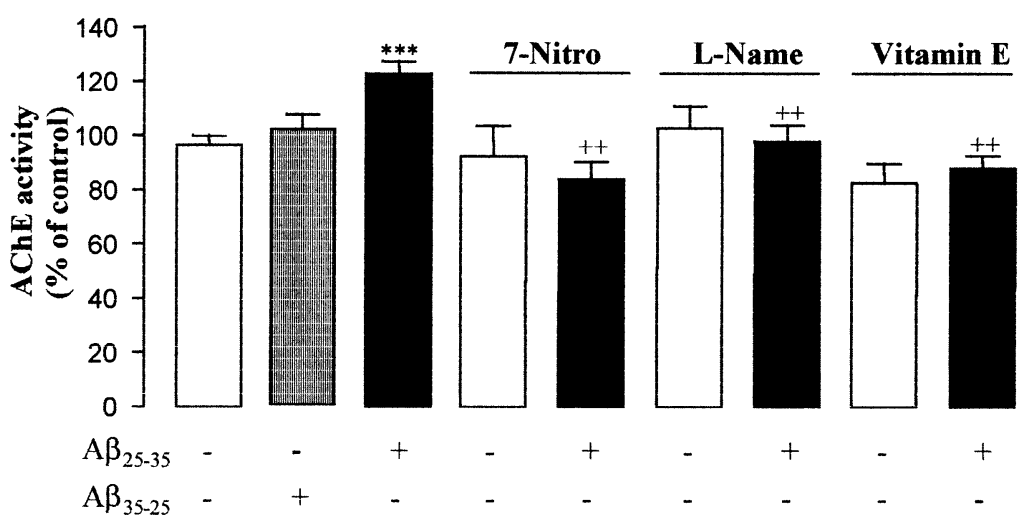

Fig. 2. AChE activity in retinal cells treated with $A \beta_{25-35}$ or $A \beta_{35-25}$ peptide $(25 \mu \mathrm{M}, 24 \mathrm{~h})$, in cells incubated with antioxidants (20 $\mu \mathrm{M}$ vitamin $\mathrm{E}$, $250 \mu \mathrm{M}$ L-NAME or $50 \mu \mathrm{M}$ 7-nitroindazole) in the absence or in the presence of $25 \mu \mathrm{M} \mathrm{A} \beta_{25-35}$, and in control cells. AChE activity was measured spectrophotometricaly using AcThCh $(0.5 \mathrm{mM})$ as a substrate and ethopropasine $\left(10^{-4} \mathrm{M}\right)$ as an inhibitor of non-specific esterases. The values were expressed as a percentage of AChE activity in control cells and are the mean \pm SEM of $8-30$ experiments. ${ }^{* * *} P<0.001$ values significantly different from cells not treated with $\mathrm{A} \beta_{25-35} ;{ }^{++} P<0.01$ values significantly different from retinal cells incubated with $\mathrm{A} \beta_{25-35}$.

from that achieved in control cells, whereas for $24 \mathrm{~h}$ of treatment a significant increase of about $30 \%$ was observed. The effect of $A \beta_{25-35}$ peptide was shown to be specific, since in the presence of the reverse sequence of the peptide AChE activity $(101.7 \pm 5.5 \%)$ was identical to that one observed in control cells $(96.4 \pm 3.4 \%)$. When AChE activity was measured in the presence of increasing substrate concentrations, an increment in enzyme activity in $A \beta_{25-35}$ treated cells was observed, although showing the same enzymatic activity profile (Fig. 3A). Fig. 3B represents the Lineweaver-Burk plot $(1 / V$ vs $1 / S)$ obtained for AChE activity of cells treated with $A \beta_{25-35}$ peptide and control cells. $K_{m}$ values, the substrate concentration that gives half of maximal reaction velocity $\left(V_{\max }\right)$, and $V_{\max }$ values were calculated by determining the $y$-intersection $\left(1 / \mathrm{K}_{\mathrm{m}}\right)$ and the $\mathrm{x}$ intersection $\left(1 / V_{\max }\right)$ of the Lineweaver-Burk plots. As can be observed in Table 2, the values of $V_{\max }$ for $\mathrm{A} \beta_{25-35}$ treated cells $(0.234 \pm 0.02 \mu \mathrm{mol}$ AchThCh/ min mgprot.) were significantly $(P<0.05)$ higher than the values determined in control cells $(0.184 \pm 0.02 \mu \mathrm{mol}$ AchThCh/min mgprot.). In contrast, the $\mathrm{K}_{\mathrm{m}}$ value was lower in cells incubated in the presence of $A \beta_{25-35}(0.068$ $\mathrm{mM})$ than in untreated cells $(0.096 \mathrm{mM})$, suggesting an increase in the substrate-AChE affinity, in the presence of the peptide.

In order to exclude the possibility of $A \beta$ inclusion in the sample might interfere with the measurement of AChE, the enzyme activity was determined after addition or not of $25 \mu \mathrm{MA} \beta_{25-35}, 15 \mathrm{~min}$ prior to the measurement, to extracts of untreated cells. Since no differences in AChE activity were observed, we can conclude that the inclusion of $A \beta$ does not interfere with the measurement of this enzyme activity (data not shown).

\subsection{Oxidative stress induced by $A \beta_{25-35}$ affects $A C h E$ activity}

In an attempt to clarify the involvement of oxidative stress in $A \beta$ neurotoxicity, we measured the accumulation of reactive oxygen species (ROS) after the exposure of the cells to $25 \mu \mathrm{MA} A \beta_{25-35}$ for $24 \mathrm{~h}$ (Fig. 4). Intracellular ROS concentration, estimated by the conversion of the fluorescent probe $\mathrm{DCFH}_{2}$-DA to $\mathrm{DCF}$, was significantly $(P<0.05)$ higher in cells incubated with the $\mathrm{A} \beta_{25-35}$ peptide for $24 \mathrm{~h}$ ( $1.25 \pm 0.05$ a.u.) or for $18 \mathrm{~h}(1.19 \pm 0.09$ a.u. $)$ than in untreated cells $(1.05 \pm 0.01$ a.u.). A pre-treatment with the antioxidant vitamin $\mathrm{E}$ $(20 \mu \mathrm{M}), 20 \mathrm{~h}$ prior to the incubation with $\mathrm{A} \beta_{25-35}$, prevented intracellular ROS production $(1.09 \pm 0.03$ a.u.). The antioxidant did not affect cell viability, as assessed by the ability of cells to reduce MTT (100.6土 $4.9 \%$ MTT reduction) or by LDH release $(13.3 \pm 1.3 \%$ $\mathrm{LDH}$ release), even when incubated during $44 \mathrm{~h}$ (data not shown). Fig. 5 shows that the incubation of retinal cells with $\mathrm{A} \beta_{25-35}$ significantly $(P<0.05)$ increased the production of TBARS $(4.36 \pm 0.44 \mathrm{nmol}$ TBARS $/ \mathrm{mg}$ prot) as compared to control cells $(2.59 \pm 0.25 \mathrm{nmol}$ TBARS/mg prot). These data suggest an increment in lipid peroxidation, that is prevented by pre-treating the cells with vitamin $\mathrm{E}(20 \mu \mathrm{M}, 20 \mathrm{~h})(2.64 \pm 0.19 \mathrm{nmol}$ TBARS/mg prot $)$ in a significant manner $(P<0.05)$. Protein carbonyl content was not affected by the incubation of retinal cells with $A \beta_{25-35}$ peptide (Table 3).

In order to understand if oxidative stress is involved in the increase of $\mathrm{AChE}$ activity induced by $\mathrm{A} \beta_{25-35}$, the effect of some antioxidants on enzyme activity was studied (Fig. 2). In cells pre-incubated with the lipophylic antioxidant vitamin $\mathrm{E}(20 \mu \mathrm{M}, 20 \mathrm{~h})$ prior to $\mathrm{A} \beta_{25-35}$ treatment $(25 \mu \mathrm{M}, 24 \mathrm{~h})$ the AChE activity 
A.

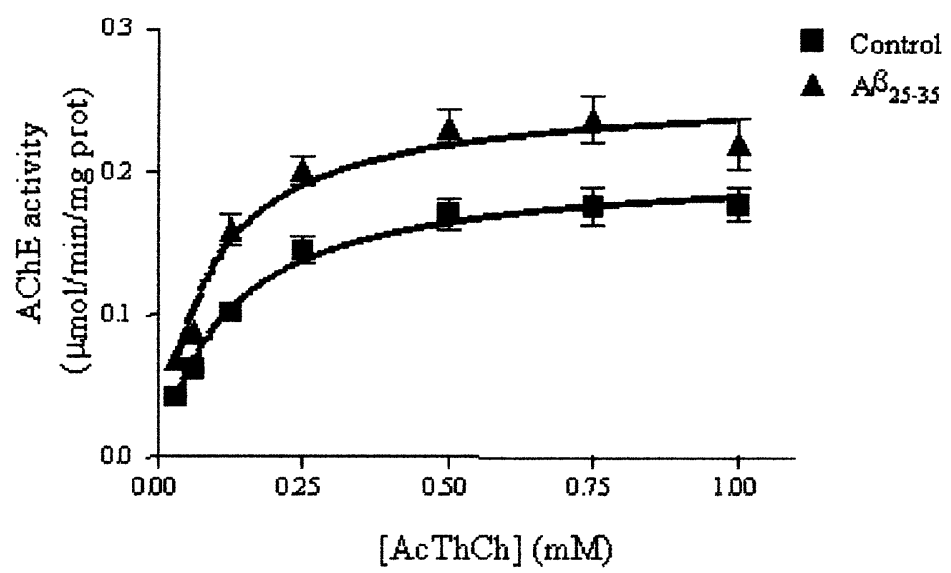

B.

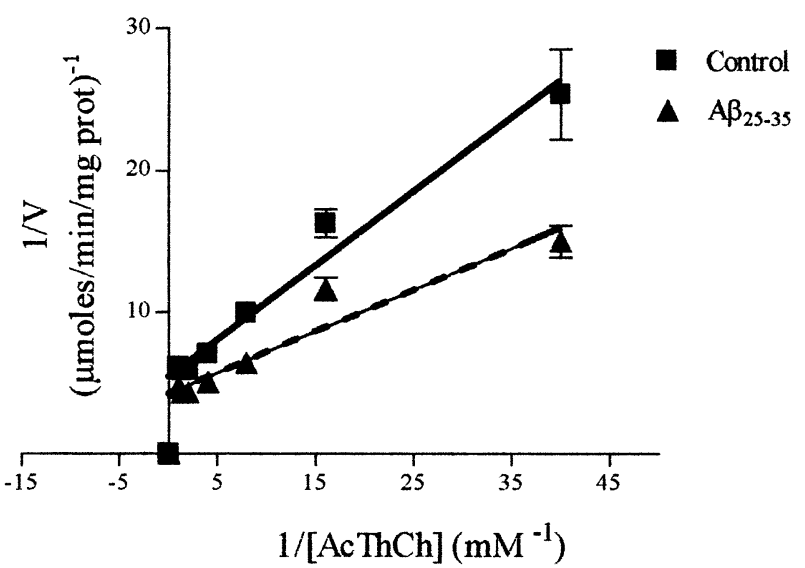

Fig. 3. (A) Activity of AChE as a function of substrate concentration in control cells ( $\mathbf{\square})$ and in cells incubated with $A \beta_{25-35}$, in a concentration of $25 \mu \mathrm{M}$, for $24 \mathrm{~h}(\boldsymbol{\Delta})$. The rate of AcThCh hydrolysis is plotted as a function of acetylthiocholine concentration $(0.03-1.00 \mathrm{mM})$. The values were expressed as micromole AcThCh hydrolysed/min/mg protein. (B) Lineweaver-Burk plots ( $1 / \mathrm{V}$ vs $1 / S)$ for AChE activity of control cells ( $\mathbf{\square})$ and for cells incubated with $25 \mu \mathrm{M} \mathrm{A} \beta_{25-35}(\mathbf{\Lambda})$. The values are mean \pm SEM of 6 independent experiments.

Table 2

Effect of $A \beta_{25-35}$ on kinetic parameters of $\mathrm{AChE}$ in retinal cells

\begin{tabular}{lll}
\hline $\begin{array}{l}\text { Experimental condi- } \\
\text { tion }\end{array}$ & $\begin{array}{l}\mathrm{K}_{\mathrm{m}} \text { value } \\
(\mathrm{mM})\end{array}$ & $\begin{array}{l}V_{\max } \text { value }(\mu \mathrm{mol} / \mathrm{min} \mathrm{mg} \\
\text { prot. })\end{array}$ \\
\hline Control & 0.096 & $0.184 \pm 0.02$ \\
$\mathrm{~A} \beta_{25-35}$ treatment & $0.068^{*}$ & $0.234 \pm 0.02^{*}$ \\
\hline
\end{tabular}

The activity of AChE was determined, as described in caption of Fig. 2, for a range of concentrations $0.03-1.0 \mathrm{mM}$ of the substrate acetylthiocholine. The values of $\mathrm{K}_{\mathrm{m}}$ and $V_{\max }$ were determined using the Lineweaver-Burk plots $(1 / V$ vs $1 / S)$ (Fig. 3B). Values represent means \pm SEM of six different experiments.

* $P<0.05$ values significantly different from control cells.

$(87.7 \pm 4.9 \%)$ was similar to that observed for untreated cells and significantly $(P<0.01)$ lower than the activity obtained for $A \beta_{25-35}$ treated cells. Pre-treatment of retinal cells with nitric oxide synthase (NOS) inhibitors, 7-nitroindazole and L-NAME, was also able of preventing the effect of $\mathrm{A} \beta_{25-35}$ on AChE activity $(83.8 \pm 6.5 \%$ and $97.7 \pm 6.0 \%$, respectively). Vitamin $\mathrm{E}$ and NOS inhibitors per se did not affect AChE activity (Fig. 2).
Furthermore, vitamin $\mathrm{E}$ was also able to prevent the change of membrane order induced by $\mathrm{A} \beta_{25-35}$. Indeed, as can be observed in Fig. 6, the anisotropy fluorescence values of TMA-DPH in cells pre-incubated with vitamin E prior $(20 \mu \mathrm{M}, 20 \mathrm{~h})$ to $A \beta_{25-35}$ treatment $(0.307 \pm$ $0.002)$ were significantly $(P<0.01)$ different from those obtained for $\mathrm{A} \beta_{25-35}$ treated cells $(0.287 \pm 0.002)$, but similar to the ones of untreated cells $(0.299 \pm 0.002)$ or treated with the reverse sequence peptide $(0.302 \pm 0.002)$.

As indicated in Table 4, the basal intracellular $\mathrm{Ca}^{2+}$ concentration $\left(\left[\mathrm{Ca}^{2+}\right]_{\mathrm{i}}\right)$, determined by using the calcium-sensitive fluorescent dye Indo-1, is significantly higher $(P<0.05)$ in $\mathrm{A} \beta_{25-35}$-treated cells $(155.0 \pm 19$ $\mathrm{nM})$ than in untreated control cells $(109.9 \pm 8.3 \mathrm{nM})$.

\section{Discussion}

The goal of this study was to test the hypothesis that $\mathrm{A} \beta_{25-35}$ enhances AChE activity and that oxidative stress plays a major role on this process. For this purpose chick embryo retina cells in culture, which 


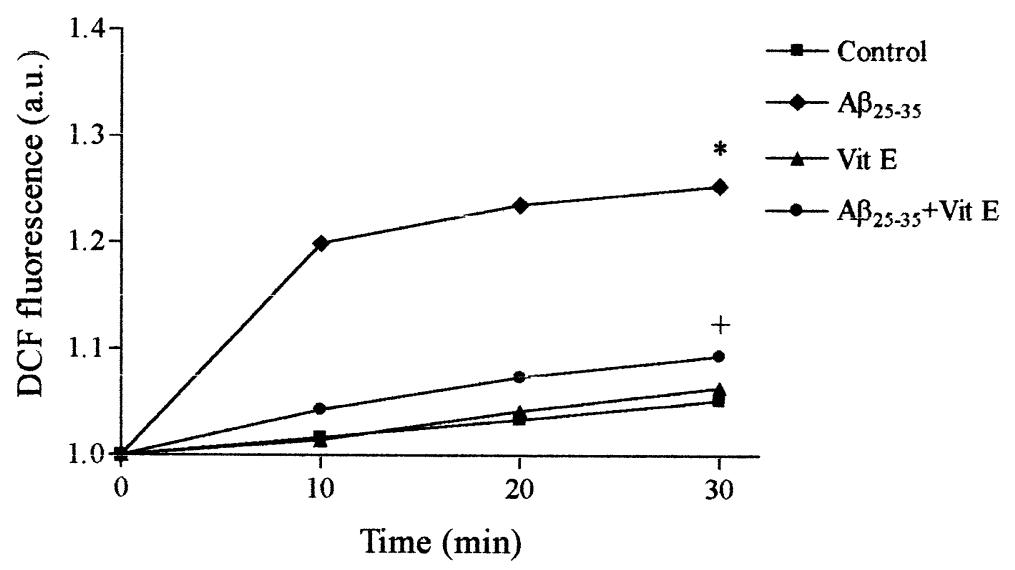

Fig. 4. DCF fluorescence of retinal cells untreated ( $\mathbf{\square})$, treated with $A \beta_{25-35}$ for $24 \mathrm{~h}(\boldsymbol{\nabla})$, incubated with vitamin $\mathrm{E}(20 \mu \mathrm{M})$ for $44 \mathrm{~h}(\boldsymbol{\Delta})$ or pretreated with vitamin $\mathrm{E}\left(20 \mathrm{~h}\right.$ prior to the addition of the peptide) and incubated with $\mathrm{A} \beta_{25-35}$ for $24 \mathrm{~h}(\mathbf{O})$. After treatment, the cells, cultured in glass coverslips, were incubated with $5 \mu \mathrm{M}$ of the fluorescent probe $\mathrm{DCFH}_{2}-\mathrm{DA}$, for $30 \mathrm{~min}$ at $37{ }^{\circ} \mathrm{C}$. After washing, fluorescence was measured using a computer-assisted spectrofluorophotometer with a thermostated cuvette holder, at $502 \mathrm{~nm}$ excitation and $550 \mathrm{~nm}$ emission, during $30 \mathrm{~min}$. DCF fluorescence indicates the formation of intracellular peroxides, as described under Section 2 . The values were expressed as arbitrary units and are the mean of 6 independent experiments. ${ }^{*} P<0.05$ significantly different compared to control condition, in the absence of $\mathrm{A} \beta_{25-35}$ peptide; ${ }^{+} P<0.05$ values significantly different from retinal cells incubated with $\mathrm{A} \beta_{25-35}$.

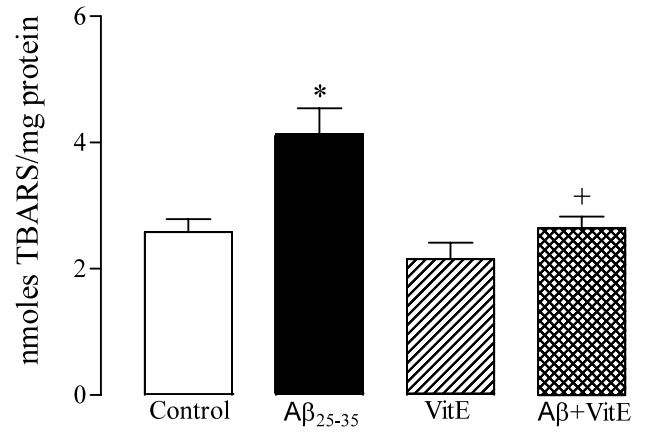

Fig. 5. Effect of vitamin $\mathrm{E}$ and of $\mathrm{A} \beta_{25-35}$ on the extent of lipid peroxidation on retinal cells. Cells were treated with vitamin $\mathrm{E}$ alone ( $20 \mu \mathrm{M}, 44 \mathrm{~h}$; Vit E), with the peptides, $A \beta_{25-35}$ or $\mathrm{A} \beta_{35-25}$ peptide, $(25 \mu \mathrm{M}, 24 \mathrm{~h})$ or with $\mathrm{A} \beta_{25-35}$ peptide in cells pre-treated $(25 \mu \mathrm{M}, 20 \mathrm{~h}$ prior to the addition of the peptide) with vitamin $\mathrm{E}(\mathrm{A} \beta+\mathrm{Vit} \mathrm{E})$. The extent of cell oxidation was determined by the TBA method, as described in Section 2, and expressed as nanomole TBARS/mg protein. Data are the mean \pm SEM of 4-11 different experiments, run in duplicate. ${ }^{*} P<0.05$ significantly different when compared to control cells; ${ }^{+} P<0.05$ values significantly different from retinal cells incubated with $\mathrm{A} \beta_{25-35}$.

Table 3

Effect of $A \beta_{25-35}$ on carbonyl content of retinal cells

\begin{tabular}{lll}
\hline & Control $(n)$ & $\mathrm{A} \beta_{25-35}(n)$ \\
\hline Carbonyl content (nmol) & $5.29 \pm 0.2(4)$ & $5.12 \pm 0.6(4)$ \\
\hline
\end{tabular}

Carbonyl content was determined after exposure of retinal cells to 25 $\mu \mathrm{M} \mathrm{A} \beta_{25-35}$, for $24 \mathrm{~h}$. Protein oxidation was determined in cell suspensions as described in Section 2. Data are expressed as mean$\mathrm{s} \pm \mathrm{SEM}$ for the number of experiments indicated, run in duplicated.

have been proved to be a good neuronal model system (Agostinho et al., 1996; Santos et al., 1998) and are highly enriched in cholinergic amacrine-like neurons

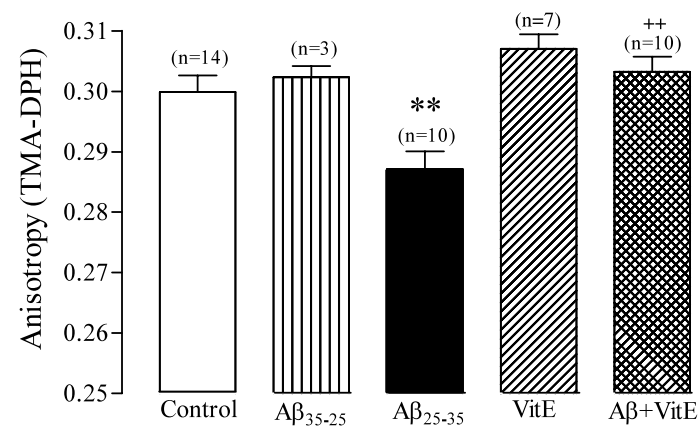

Fig. 6. Effect of vitamin $\mathrm{E}$ and of $\mathrm{A} \beta_{25-35}$ peptide on membrane order. Cells were treated with vitamin $\mathrm{E}$ alone $(20 \mu \mathrm{M}, 44 \mathrm{~h}$; Vit $\mathrm{E})$, with the peptides, $A \beta_{25-35}$ or $A \beta_{35-25}$ peptide, $(25 \mu \mathrm{M}, 24 \mathrm{~h})$ or with $\mathrm{A} \beta_{25-35}$ peptide in cells pre-treated $(25 \mu \mathrm{M}, 20 \mathrm{~h}$ prior to the addition of the peptide) with vitamin $\mathrm{E}(\mathrm{A} \beta+\mathrm{Vit} \mathrm{E})$. Cells were incubated with $1.5 \mu \mathrm{M}$ TMA-DPH in sodium saline solution ( $\mathrm{pH} \mathrm{7.4)} \mathrm{for} 20 \mathrm{~min}$, at $37{ }^{\circ} \mathrm{C}$. Fluorescence anisotropy $(r)$ was determined using a computerassisted spectrofluorophotometer, with a thermostated cuvette holder and a controlled polarizer system, with excitation at $360 \mathrm{~nm}$ and emission at $430 \mathrm{~nm}$. The values of anisotropy $(r)$ are the means \pm SEM of the number of indicated experiments. ${ }^{* *} P<0.01$ values significantly different from control cells; ${ }^{++} P<0.01$ values significantly different from retinal cells incubated with $\mathrm{A} \beta_{25-35}$.

(Carvalho et al., 1998; Santos et al., 1998), were used. The sequence corresponding to amino acids $25-35$ of $\mathrm{A} \beta\left(\mathrm{A} \beta_{25-35}\right)$ forms fibrils and is neurotoxic by a mechanism similar to that of the full-length peptides $\mathrm{A} \beta_{1-40}$ or $\mathrm{A} \beta_{1-42}$ (Yankner et al., 1990; Pike et al., 1993). The concentration of $A \beta$ used in this work (25 $\mu \mathrm{M})$ corresponds approximately to the levels found in post-mortem brains of AD patients. The concentration of $A \beta$ found has been calculated to be in the order of $100 \mu \mathrm{g} / \mathrm{g}$ of tissue (Hyman et al., 1993), which corresponds to approximately $20 \mu \mathrm{M}$, assuming a tissue density of $1 \mathrm{~g} / \mathrm{ml}$ (Huang et al., 1999). 
Table 4

Effect of $A \beta_{25-35}$ on intracellular calcium levels of retinal cells

\begin{tabular}{lll}
\hline & Control $(n)$ & $\mathrm{A} \beta_{25-35}(n)$ \\
\hline$\left[\mathrm{Ca}^{2+}\right]_{\mathrm{i}}$ basal $(\mathrm{nM})$ & $109.9 \pm 8.3(10)$ & $155.0 \pm 19 *(6)$ \\
\hline
\end{tabular}

After exposure or not (control) to $\mathrm{A} \beta_{25-35}(25 \mu \mathrm{M})$ for $24 \mathrm{~h}$, retinal cells were loaded with Indo-AM for $45 \mathrm{~min}$ at $37{ }^{\circ} \mathrm{C}$. Cells were further incubated in Krebs buffer for $15 \mathrm{~min}$, in order to obtain the hydrolysis of the probe to Indo-1. Intracellular calcium levels were determined by spectrofluorophotometry with excitation wavelength of $335 \mathrm{~nm}$ and emission at $410 \mathrm{~nm}$. Values represent means \pm SEM of the number of experiments indicated.

* $P<0.05$ significantly different compared to control condition, in the absence of $\mathrm{A} \beta_{25-35}$ peptide.

In our experimental conditions, $A \beta_{25-35}$ treatment did not affect retinal cell membrane integrity, given by LDH release (Table 1). However, the cellular metabolic capacity, evaluated by MTT assay, showed to be compromised by the exposure to the amyloidogenic peptide (Table 1). These data suggest that $A \beta_{25-35}$ treatment induced a moderate cell injury, since membrane cell integrity was not significantly altered. Several mechanisms have been proposed for $\mathrm{A} \beta$ peptidesmediated neurotoxicity. Some authors reported that in a conformation-dependent manner $\mathrm{A} \beta$ and the $\mathrm{C}$ terminal region of APP compromise neurons viability via the rapid disruption of intracellular $\mathrm{Ca}^{2+}$ homeostasis (Mattson et al., 1992, 1995; Fraser et al., 1996) and that $\mathrm{A} \beta$ potentiates glutamate toxicity by the generation of $\mathrm{Ca}^{2+}$ transmembrane fluxes (Gray and Pattel, 1995).

Another mechanism suggested to be involved in $A \beta$ peptides-induced neurotoxicity is the generation of ROS (Behl et al., 1994; Butterfield et al., 1994; Pereira et al., 1999) which seems to be responsible for cell membrane lipid peroxidation (Mattson et al., 1992; Behl et al., 1994; Mark et al., 1997b). Peroxidation of membrane unsaturated fatty acids generates several aldehydes, such as malonildialdehyde and 4-hydroxy-2,3-nonenal (4HNE) (Esterbauer et al., 1991). 4-HNE was also shown to be generated by $\mathrm{A} \beta$ (Mark et al., 1997a), impairing the function of membrane proteins, such as ion-motive ATPases and voltage $\mathrm{Ca}^{2+}$ channels, that ultimately lead to the disruption of ion homeostasis (Mark et al., 1997b). The three isoforms (neuronal, endothelial and inducible) of the nitric oxide-synthesizing enzyme, NOS, are aberrantly expressed in $\mathrm{AD}$ giving rise to elevated levels of nitric oxide (NO). In addition to its vasoactive and immunological properties, $\mathrm{NO}$ has significant neurophysiological functions. However, NO can also be neurotoxic primarily due to its free radical properties (Law et al., 2001b). NO seems to be involved in AD by different mechanisms including oxidative stress and activation of intracellular signalling mechanisms (Luth et al., 2001). A $\beta$ showed to increase NO release, decreasing cellular viability, in primary cortical cultures (Law et al., 2001a) and to increase NO production in rat hippocampus (Tran et al., 2001). We have observed that A $\beta_{25-35}$ increases significantly $(P<0.05)$ ROS production (Fig. 4) and lipid peroxidation levels (Fig. 5), and that pre-treatment of the cells with the antioxidant vitamin $\mathrm{E}(20 \mu \mathrm{M})$ prevents these oxidative events. Rego et al. (1998) have also shown that vitamin $\mathrm{E}$, in the concentration used in this study and during the same incubation period, reduces the extent of lipid peroxidation when chick retinal cells are exposed to peroxidizing conditions. We have also observed that $\mathrm{A} \beta_{25-35}$ increases basal $\left[\mathrm{Ca}^{2+}\right]_{i}$ (Table 4). There is growing evidence for a possible link between an increase in $\left[\mathrm{Ca}^{2+}\right]_{\mathrm{i}}$ and an enhanced generation of ROS (Dutrait et al., 1995; Mattson et al., 1995). Recent reports show that an increase in cell $\mathrm{Ca}^{2+}$ influx, mainly through voltagesensitive $\mathrm{Ca}^{2+}$ channels, precedes ROS formation and the subsequent lipid peroxidation in cultured cells exposed to A $\beta$ (Ekinci et al., 1999, 2000), suggesting that the concerted appearance of these neurotoxic events may accelerate $A \beta$-induced neuronal damage (Mattson, 1998).

A direct consequence of lipid peroxidation is the alteration of cell membrane order (Rego and Oliveira, 1995). We observed an increase in membrane fluidity in retinal cells exposed to the amyloidogenic peptide, $\mathrm{A} \beta_{25-35}$, by using the fluorescent probe TMA-DPH (Fig. 6). Changes in TMA-DPH fluorescent anisotropy mainly reflect the alteration of membrane order in the glycerol and upper regions of the lipid bilayer (Prendergast et al., 1981). At the initial periods of peroxidation the decrease in membrane order indicates a disordering effect at the level of phospholipid head groups and at the upper part of fatty acyl chains, whereas the progression of fatty acyl chain oxidation may contribute to the enhancement of cell membrane rigidity (Dobretsov et al., 1977; Rego and Oliveira, 1995). The $A \beta_{25-35}$-induced increase of cell membrane fluidity (lower values of TMA-DPH fluorescence anisotropy) was prevented by the antioxidant vitamin E (Fig. 6 ), further supporting the hypothesis that $A \beta_{25-35}$ induces oxidative stress and membrane lipid peroxidation.

Several studies in AD brains have demonstrated that changes occur in the expression and distribution of AChE (Massoulié et al., 1993). Furthermore, most of the cortical AChE activity present in AD brains has been found associated with senile plaques, where it colocalizes with $A \beta$ deposits (Kasa et al., 1997). In vitro, AChE promotes the aggregation of $A \beta$ in amyloid fibrils (Inestrosa et al., 1996) and forms a complex with $A \beta$, which has a higher toxic effect than $\mathrm{A} \beta$ (Alvarez et al., 1997, 1998). These authors also reported that the kinetic properties of $\mathrm{A} \beta$-AChE complexes differ from those of 
the free enzyme, with $\mathrm{K}_{\mathrm{m}}$ and $V_{\max }$ values higher for $\mathrm{A} \beta$-AChE, the complexed enzyme being more resistant to low $\mathrm{pH}$ conditions, to inhibition by anticholinestease agents or by the excess of substrate. We report here that $\mathrm{A} \beta_{25-35}$ peptide leads to a significant $(P<0.001)$ increment in AChE activity, with an increase in $V_{\max }$ and a decrease in $\mathrm{K}_{\mathrm{m}}$ values (Table 2). These results suggest that a change in enzyme conformation occurs, leading to an increase in substrate-enzyme affinity (lower $\mathrm{K}_{\mathrm{m}}$ values) and enzyme activity. The effect observed for $A \beta_{25-35}$ is specific of this neurotoxic sequence, because the reverse sequence peptide, $\mathrm{A} \beta_{35-25}$, did not affect cell viability or AChE activity (Table 1 and Fig. 2). In accordance with our results, $A \beta$ was shown to induce the expression of AChE in the brains of CT-100-expressing transgenic mice (Sberna et al., 1998). Furthermore, in another study using human CSF samples, $A \beta$ levels were found to have a significant and positive correlation with cholinesterase activity (Carroll et al., 1999). Sberna et al. (1997) reported that $\mathrm{A} \beta$ increments AChE activity in P19 cells by increasing calcium entry through L-type voltage-dependent calcium channels, suggesting that the increase of $\mathrm{AChE}$ expression around amyloid plaques is a consequence of a disturbance of calcium homeostasis. In our experimental conditions, we also observed an increase in basal $\mathrm{Ca}^{2+}$ intracellular levels induced by $\mathrm{A} \beta$, which can be related to the increase in AChE activity. We also showed that vitamin $\mathrm{E}$, a well-known lipid peroxidation chain breaking antioxidant, and NOS inhibitors (7-Nitroindazole and L-NAME) prevent $A \beta_{25-35}$-induced $\mathrm{AChE}$ activity enhancement. This evidence suggests a role for ROS on the increase of AChE activity. Moreover, after $18 \mathrm{~h}$ incubation with $\mathrm{A} \beta_{25-35}$ ROS levels increase, although the activity of AChE $(112 \pm 7.7 \%)$ was not significantly $(P>0.05)$ affected, suggesting that ROS generation precedes the increase of AChE. An indirect role for $\mathrm{Ca}^{2+}$ influx in the impairment of enzyme activity, leading to an increase in ROS production and consequently to membrane lipid peroxidation, cannot be ruled out. It is likely that the impairment of AChE is due to lipid peroxidation and changes in membrane order rather than to protein oxidation, because the content in carbonyl group was not affected by $\mathrm{A} \beta$ treatment (Table 3).

Taken together our data suggest that calcium influx followed by oxidative stress is involved in the increased activity of $\mathrm{AChE}$ induced by $\mathrm{A} \beta_{25-35}$ peptide, decreasing cell membrane order and ultimately leading to the exposure of more active sites of the enzyme. The observation that $\mathrm{A} \beta$ peptide increases $\mathrm{AChE}$ activity and ROS production indicates that it can be possible to ameliorate cholinergic function, by inhibiting $A \beta$-induced increase in AChE activity.

\section{Acknowledgements}

The present work was supported by FCT (Portuguese Research Council).

\section{References}

Abe, K., Saito, H., 1999. Both oxidative stress-dependent and independent effects of amyloid beta protein are detected by 3 (4,5-dimethylthiazol-2-yl)-2, 5-diphenyltetrazolium bromide (MTT) reduction assay. Brain Res. 830, 146-154.

Agostinho, P., Duarte, C.B., Carvalho, A.P., Oliveira, C.R., 1994. Effect of oxidative stress on the release of $\left[^{3} \mathrm{H}\right] \mathrm{GABA}$ in cultured chick retina cells. Brain Res. 655, 213-221.

Agostinho, P., Duarte, C.B., Carvalho, A.P., Oliveira, C.R., 1997. Oxidative stress affects the selective ion permeability of voltagesensitive $\mathrm{Ca}^{2+}$ channels in cultured retinal cells. Neurosci. Res. 27, $323-334$.

Agostinho, P., Duarte, C.B., Oliveira, C.R., 1996. Activity of ionotropic glutamate receptors in retinal cells: effect of ascorbate/ $\mathrm{Fe}^{2+}$-induced oxidative stress. J. Neurochem. 67, 1153-1163.

Alvarez, A., Alarcón, R., Opazo, C., Campos, E.O., Muñoz, F.J., Caldéron, F.H., Dajas, F., Gentry, M.K., Doctor, B.P., De Mello, F.G., Inestrosa, N.C., 1998. Stable complexes involving acetylcholinesterase and amyloid- $\beta$ peptide change the biochemical properties of the enzyme and increase the neurotoxicity of Alzheimer's fibrils. J. Neurosci. 18, 3213-3223.

Alvarez, A., Opazo, C., Alarcón, R., Garrido, J., Inestrosa, N.C., 1997. Acetylcholinesterase promotes the aggregation of amyloid- $\beta$ peptide fragments by forming a complex with growing fibrils. J. Mol. Biol. 272, 348-361.

Atack, J.R., Perry, E.K., Bonham, J.R., Perry, R.H., Tomlinson, B.E., Blessed, G., Fairbairn, A., 1983. Molecular forms of acetylcholinesterase in senile dementia of Alzheimer's type: selective loss of the intermediate (10S) form. Neurosci. Lett. 40, 199-204.

Behl, C., Davis, J.B., Cole, G.M., Shubert, D., 1992. Vitamin E protects nerve cells from amyloid $\beta$-protein toxicity. Biochem. Biophys. Res. Commun. 186, 944-950.

Behl, C., Davis, J.B., Lesley, R., Schubert, D., 1994. Hydrogen peroxide mediates amyloid $\beta$-protein toxicity. Cell 77, 817-827.

Bergmeyer, H.U., Brent, E., 1974. UV-assay with pyruvate and NADH. In: Bergmeyer, H.U. (Ed.), Methods of Enzymatic Analysis. Academic Press, New York, pp. 574-579.

Buege, J.A., Aust, S.D., 1967. Microsomal lipid peroxidation. Methods Enzymol. 52, 302-310.

Bus, A.I., Huang, X., Fairlie, D.P., 1999. The possible origin of free radicals from amyloid $\beta$-peptides in Alzheimer's disease. Neurobiol. Aging 20, 335-337.

Butterfield, D.A., Hensley, K., Harris, M., Mattson, M., Carney, J., 1994. $\beta$-amyloid peptide free radical fragments initiate synaptosomal lipoperoxidation in a sequence-specific fashion: implications to Alzheimer's disease. Biochem. Biophys. Res. Commun. 200, 710715 .

Cardoso, S.M., Pereira, C., Oliveira, C.R., 1999. Mitochondrial function is differently affected upon oxidative stress. Free Radical Biology \& Medicine 26, 3-13.

Carroll, R.T., Lust, M.R., Emmerling, M.R., 1999. Beta-amyloid levels predict cholinesterase activity in human cerebrospinal fluid. Neuroreport 10, 127-130.

Carvalho, A.L., Duarte, C.B., Faro, C.J., Carvalho, A.P., Pires, E.V., 1998. Calcium influx through AMPA receptors and through calcium channels is regulated by protein kinase $\mathrm{C}$ in cultured retina amacrine-like cells. J. Neurochem. 70, 2112-2119. 
Cathcart, R., Schwiers, E., Ames, B.N., 1983. Detection of picomole levels of hydroperoxides using a fluorescent dichlorofluorescein assay. Anal. Biochem. 134, 111-116.

Dobretsov, G.E., Borschievskaya, T.A., Petrov, V.A., Vladimirov, Y.A., 1977. The increase of phospholipid bilayer rigidity after lipid peroxidation. FEBS Lett. 84, 125-128.

Dutrait, N., Culcasi, M., Cazevieille, C., Pietri, S., Tordo, P., Bonne, C., Muller, A., 1995. Calcium-dependent free radical generation in cultured retinal neurons induced by kainate. Neurosci. Lett. 198, $13-16$.

Ekinci, F.J., Linsley, M.-D., Shea, T.B., 2000. $\beta$-Amyloid-induced calcium influx induces apoptosis in culture by oxidative stress rather than tau phosphorylation. Mol. Brain Res. 76, 389-395.

Ekinci, F.J., Malik, K.M., Shea, T.B., 1999. Activation of the $L$ voltage-sensitive calcium channel by mitogen-activated protein (MAP) kinase following exposure of neuronal cells to $\beta$-amyloid. MAP kinase mediates $\beta$-amyloid-induced neurodegeneration. J. Biol. Chem. 274, 30322-30327.

Ellman, G.L., Courtney, K.D., Anders, V., Featherstone, R.M., 1961. A new and rapid colorimetric determination of acetylcholinesterase activity. Biochem. Pharmacol. 7, 88-95.

Esterbauer, H., Schaur, R.J., Zollner, H., 1991. Chemistry and biochemistry of 4-hydroxynonenal, malonaldehyde and related aldehydes. Free Rad. Biol. Med. 11, 81-128.

Fraser, S.P., Suh, Y.-H., Chong, Y.H., Djamgoz, M.B.A., 1996. Membrane currents induced in Xenopus oocytes by the C-terminal fragment of the $\beta$-amyloid precursor protein. J. Neurochem. 66, 2034-2040.

Geula, C., Mesulam, M.-M., 1994. Cholinergic systems and related neuropathological predilection patterns in Alzheimer disease. In: Terry, R.D., Katzman, R., Bick, K.L. (Eds.), Alzheimer Disease. Raven press, New York, pp. 263-291.

Gray, C.W., Pattel, A.J., 1995. Neurodegeneration mediated by glutamate and $\beta$-amyloid peptide: a comparison and possible interaction. Brain Res. 691, 169-179.

Harkany, T., Mulder, J., Sasvári, M., Ábrahám, I., Kónya, C., Zarándi, M., Penke, B., Luiten, P.G.M., Nyakas, C., 1999. Nmethyl-D-Aspartate receptor antagonist MK-801 and radical scavengers protect cholinergic nucleus basalis neurons against $\beta$ amyloid neurotoxicity. Neurobiol. Dis. 6, 109-121.

Huang, X., Atwood, C.S., Hartshorn, M.A., Multhaup, G., Golldstein, L.E., Scarpa, R.C., Cuajungco, M.P., Gray, D.N., Lim, J., Moir, R.D., Tanzi, R.E., Bush, A.I., 1999. The A $\beta$ peptide of Alzheimer's disease directly produces hydrogen peroxide through metal ion reduction. Biochemistry 38, 7609-7616.

Hyman, B.T., Marzloff, K., Arriagada, P.V., 1993. The lack of accumulation of senile plaques or amyloid burden in Alzheimer's disease suggests a dynamic balance between amyloid deposition and resolution. J. Neuropathol. Exp. Neurol. 52, 594-600.

Inestrosa, N.C., Alvarez, A., Pérez, C.A., Moreno, R.D., Vicente, M., Linker, C., Casanueva, O.I., Soto, C., Garrido, J., 1996. Acetylcholinesterase accelerates assembly of amyloid $\beta$-peptides into Alzheimer's fibrils: possible role of the peripheral site of the enzyme. Neuron 16, 881-891.

Kang, J., Lenmaire, H.-G., Unterbeck, A., Salbaum, M.N., Masters, C.L., Grzeschik, K.-H., Multhaup, G., Beyreuther, K., MuellerHill, B., 1987. The precursor protein of Alzheimer's disease amyloid A4 protein resembles a cell surface receptor. Nature 325, 733-736.

Kasa, P., Papp, H., Kovacs, I., Forgon, M., Penke, B., Yamaguchi, H., 2000. Human amyloid- $\beta$ 1-42 applied in vivo inhibits the fast axonal transport of proteins in the sciatic nerve of rat. Neurosci. Lett. 278, 117-119.

Kasa, P., Rakonczany, Z., Gulya, K., 1997. The cholinergic system in Alzheimer's disease. Prog. Neurobiol. 52, 511-535.

Levine, R.L., Garland, D., Oliver, C.N., Amici, A., Climent, I., Lenz, A.G., Ahn, B.-W., Shaltiel, S., Stadtman, E.R., 1990. Determina- tion of carbonyl content in oxidatively modified proteins. Methods Enzymol. 186, 464-478.

Law, A., Gauthier, S., Quirion, R., 2001a. Neuroprotective and neurorescuing effects of isoform-specific nitric oxide synthase inhibitors, nitric oxide scavenger, and antioxidant against betaamyloid toxicity. Br. J. Pharmacol. 133, 1114-1124.

Law, A., Gauthier, S., Quirion, R., 2001b. Say NO to Alzheimer's disease: the putative links between nitric oxide and dementia of the Alzheimer's type. Brain Res. Rev. 1, 73-96.

Liu, Y., Schubert, D., 1997. Cytotoxic amyloid peptides inhibit cellular3-(4,5-dimethylthiazol-2-yl)-2,5-diphenyltetrazolium bromide (MTT) reduction by enhancing MTT formazan exocytosis. J Neurochem. 69, 2285-2293.

Luth, H., Holzer, M., Gartner, U., Staufenbiel, M., Arendt, T., 2001. Expression of endothelial and inducible NOS-isoforms is increased in Alzheimer's disease, in APP23 transgenic mice and after experimental brain lesion in rat: evidence for an induction by amyloid pathology. Brain Res. 913, 57-67.

Mark, R.J., Lovell, M.A., Markesberry, W.R., Uchida, K., Mattson, M.P., 1997a. A role for 4-hidroxynonenal, an aldehydic product of lipid peroxidation, in disruption of ion homeostasis and neuronal death induced by amyloid $\beta$-peptide. J. Neurochem. 68, $255-264$

Mark, R.J., Pang, Z., Geddes, J.W., Uchida, K., Mattson, M.P., 1997b. Amyloid $\beta$-peptide impairs glucose transport in hippocampal and cortical neurons: involvement of membrane lipid peroxidation. J. Neurosci. 17, 1046-1054.

Mattson, M.P., 1998. Modification of ion homeostasis by lipid peroxidation: roles in neuronal degeneration and adaptive plasticity. Trends Neurosci. 21, 53-57.

Mattson, M.P., Barger, S.W., Begley, J.G., Mark, R.J., 1995. Calcium, free radicals, and excitotoxic neuronal death in primary cell culture. Methods Cell Biol. 46, 187-216.

Mattson, M.P., Cheng, B., Davis, D., Bryant, K., Lieberburg, I., Rydel, R.E., 1992. $\beta$-Amyloid peptides destabilize calcium homeostasis and render human cortical neurons vulnerable to excitotoxicity. J. Neurosci. 12, 379-389.

Massoulié, J., Pezzementi, L., Bon, S., Krejci, E., Vallette, F.M., 1993. Molecular and cellular biology of cholinesterases. Prog. Neurobiol. $41,31-91$.

Melo, J.B., Agostinho, P., Oliveira C.R. Amyloid beta-peptide reduces $\left[{ }^{3} \mathrm{H}\right]$ acetylcholine release in retinal neurons. Involvement of metabolic dysfunction. Amyloid, in press.

Morán, M.A., Mufson, E.J., Gómez-Ramos, P., 1993. Colocalization of cholinesterases with $\beta$ amyloid protein in aged and Alzheimer's brains. Acta Neuropathol. 85, 362-369.

Mosmann, T., 1983. Rapid colorimetric assay for cellular growth and survival. J. Immunol. Methods 65, 55-63.

Pereira, C., Santos, M.S., Oliveira, C., 1999. Involvement of oxidative stress on the impairment of energy metabolism induced by A $\beta$ peptides on PC12 cells: protection by antioxidants. Neurobiol. Dis. 6, 209-219.

Pike, C.J., Burdick, D., Walencewicz, A.J., Glabe, C.J., Cotman, C.W., 1993. Neurodegeneration induced by $\beta$-amyloid peptides in vitro: the role of protein assembly state. J. Neurosci. 13, 16761687.

Prendergast, F.G., Haugland, R.P., Callahan, P.J., 1981. 1-[4-(trimethylamino)phenyl-6-phrnylhexa-1,3,5-triene: synthesis, fluorescence properties, and use as a fluorescence probe of lipid bilayers. Biochemistry 20, 7333-7338.

Rego, A.C., Oliveira, C.R., 1995. Dual effect of lipid peroxidation on the membrane order of retinal cells in culture. Arch. Biochem. Biophys. 321, 127-136.

Rego, A.C., Santos, M.S., Proença, M.T., Oliveira, C.R., 1998. Influence of vitamin $\mathrm{E}$ succinate on retinal cell survival. Toxicology $128,113-124$. 
Santos, P.F., Santos, M.S., Carvalho, A.P., Duarte, C.B., 1998 Modulation of $\left[{ }^{3} \mathrm{H}\right]$ Acetylcholine release from cultured amacrinelike neurons by adenosine A1 receptors. J. Neurochem. 71, 10861094.

Sberna, G., Saez-Valero, J., Beyreuther, K., Masters, C.L., Small, D.H., 1997. The amyloid beta-protein of Alzheimer's disease increases acetylcholinesterase expression by increasing intracellular calcium in embryonal carcinoma P19 cells. J. Neurochem. 69, $1177-1184$.

Sberna, G., Saez-Valero, J., Li, Q.X., Czech, C., Beyreuther, K., Masters, C.L., McLean, C.A., Small, D.H., 1998. Acetylcholinesterase is increased in the brains of transgenic mice expressing the $\mathrm{C}$ terminal fragment (CT100) of the beta-amyloid protein precursor of Alzheimer's disease. J. Neurochem. 71, 723-731.

Sedmak, J.J., Grossero, S.E., 1977. A rapid sensitive and versatile assay for protein using Coomassie Brilliant Blue G250. Anal. Biochem. 79, 544-552.

Shinitzky, M., Barenholz, Y., 1978. Fluidity parameters of lipid regions determined by fluorescence polarization. Biochim. Biophys. Acta 555, 367-394.

Tanzi, R.E., McClatchey, A.I., Lamperti, E.D., Villa-Komaroff, L.T., Gusella, J.F., Neve, R.L., 1988. Protease inhibitor domain encoded by an amyloid protein precursor mRNA associated with Alzheimer's disease. Nature 331, 528-530.

Tran, M.H., Yamada, K., Olariu, A., Mizuno, M., Ren, X.H., Nabeshima, T., 2001. Amyloid $\beta$-peptide induces nitric oxide production in rat hippocampus: association with cholinergic dysfunction and amelioration by inducible nitric oxide synthase inhibitors. FASEB J. 10.1096/fj.00-0719fje.

Ulrich, J., Meier-Ruge, W., Probst, A., Meier, E., Ipsen, S., 1990. Senile plaques: staining for acetylcholinesterase and A4 protein: a comparative study in the hippocampus and entorhinal cortex. Acta Neuropathol. 80, 624-628.

Van Blitterswijk, W.J., Van Hoeven, R.P., Van der Meer, B.W., 1981. Lipid structural order parameters (reciprocal of fluidity) in biomembranes derived from steady-state fluorescence polarization measurements. Biochim. Biophys. Acta 644, 323-332.

Yankner, B.A., Duffy, L.K., Kirschner, D.A., 1990. Neurotrophic and neurotoxic effects of amyloid beta protein: reversal by tachykinin neuropeptides. Science 250, 279-282.

Zhu, Y.J., Lin, H., Lal, R., 2000. Fresh and nonfibrillar amyloid $\beta$ protein $(1-40)$ induces rapid cellular degeneration in aged human fibroblasts: evidence for A $\beta$ P-channel-mediated cellular toxicity. FASEB J. 14, 1244-1254. 